\title{
PENGARUH KINERJA DRIVER DAN FASILITAS APLIKASI TERHADAP LOYALITAS MELALUI KEPUASAN PELANGGAN (Studi Kasus Gojek Kota Malang)
}

\author{
Ratna Nikin Hardati \\ Dosen JurusanAdministrasi Bisnis, Fakultas Ilmu Administrasi Universitas Islam Malang \\ Email: ratna.n.hardati@gmail.com
}

\begin{abstract}
Gojek, an online transportation service provider, is a social-spirited company that is leading the revolution in the ojek transportation industry. Gojek partners with experienced ojek riders to be the main solution in shipping goods, ordering food delivery, shopping and traveling in a traffic jam. The purpose of this study is to explain the effect of: Driver Performance on Customer Satisfaction, Effect of Application Facilities on Customer Satisfaction and Effect of Driver Performance and Application Facilities on Loyalty through Customer Satisfaction. This research is a quantitative research. The research population is Gojek customers in Malang City. The number of samples used was determined by the Proportional Random Sampling technique. Data analysis using the path analysis method (Path Analysis). The results showed that there was a significant influence between the performance of the driver on customer satisfaction Gojek; There is a significant influence between facilities on customer satisfaction Gojek; There is a significant influence between driver performance and facilities simultaneously on customer satisfaction) Gojek; There is a significant influence between driver performance on customer loyalty Gojek; The existence of insignificant influence between facilities on customer loyalty Gojek; There is a significant influence between satisfaction on customer loyalty Gojek; and the existence of significant influence between the effect of driver performance, facilities, and satisfaction simultaneously on Gojek customer loyalty.
\end{abstract}

\section{Keywords: Driver, Customer Satisfaction, Facilities, Performance}

\begin{abstract}
ABSTRAK
Gojek merupakan salah satu penyedia jasa transportasi online adalah perusahaan berjiwa sosial yang memimpin revolusi industry transportasi ojek. Gojek bermitra dengan para pengendara ojek berpengalaman menjadi solusi utama dalam pengiriman barang, pesan antar makanan, berbelanja dan berpergian ditengah kemacetan. Tujuan penelitian ini untuk menjelaskan pengaruh : Kinerja Driver terhadap Kepuasan Pelanggan, Pengaruh Fasilitas Aplikasi terhadap Kepuasan Pelanggan dan Pengaruh Kinerja Driver dan Fasilitas Aplikasi terhadap Loyalitas melalui Kepuasan Pelanggan. Penelitian ini adalah penelitian kuantitatif. Populasi penelitiannya pelanggan Gojek di Kota Malang. Jumlah sampel yang digunakan ditentukan dengan teknik Proportional Random Sampling. Analisis data menggunakan metode analisis jalur (Path Analysis). Hasil penelitian menunjukkan bahwa adanya pengaruh signifikan antara kinerja driver terhadap kepuasan pelanggan Gojek; Adanya pengaruh signifikan antara fasilitas terhadap kepuasan pelanggan Gojek; Adanya pengaruh signifikan antara kinerja driver dan fasilitas secara simultan terhadap kepuasan pelanggan Gojek; Adanya pengaruh signifikan antara kinerja driver terhadap loyalitas pelanggan Gojek; Adanya pengaruh yang tidak signifikan antara fasilitas terhadap loyalitas pelanggan Gojek; Adanya pengaruh yang signifikan antara kepuasan terhadap loyalitas pelanggan Gojek; dan Adanya pengarug yang dignifikan antara pengaruh kinerja driver, fasilitas dan kepuasan secara simultan terhadap Loyalitas pelanggan Gojek.
\end{abstract}

Kata Kunci : Driver, Kepuasan Pelanggan, Fasilitas, Kinerja 


\section{PENDAHULUAN}

Di era yang modern seperti sekarang ini, transportasi menjadi salah satu penunjang penting dalam kegiatan sehari - hari terutama di daerah perkotaan. Transportasi yang baik dapat menciptakan keteraturan kota yang baik, hal ini disebabkan karena transportasi merupakan suatu alat bantu dalam mengarahkan pembangunan di daerah perkotaan. Transportasi dapat membantu perekonomian yang baik di suatu daerah bahkan disuatu Negara (Fahrida, 2011). Semakin baik dan tertatanya transportasi di suatu daerah akan semakin baik pula perekonomiannya. Dengan adanya pertumbuhan penduduk yang semakin meningkat mempengaruhi kebutuhan akan jasa transportasi yang semakin meningkat pula, hal ini lah yang menyebabkan semakin berkembangnya dunia bisnis di sector jasa transportasi.

Dengan bermunculannya berbagai masalah transportasi, semakin banyak pula bisnis disektor jasa transportasi baik itu bisnis skala besar seperti taxi, bus dan lain-lain. Persaingan antar perusahaan di era globalisasi semakin tajam, sehingga sumber daya manusia (SDM) dituntut untuk terus menerus mampu mengembangkan diri secara proaktif. Dalam kondisi tersebut integritas pribadi semakin penting untuk memenangkan persaingan. Pengembangan sumber daya manusia berbasis kompetensi dilakukan agar dapat memberikan hasil yang sesuai dengan tujuan dan sasaran organisasi dengan standart kinerja yang telah ditetapkan. (Gaol, 2013). Sejalan dengan pesatnya teknologi, teknologi transportasipun tak kalah berkembang pesatnya. Saat ini banyak bermunculan jasa transportasi online di Indonesia seperti GO-JEK ,Grabbike, Grabtaxi, Uber, Bajaj App dan lain-lain.

GO-JEK merupakan salah satu penyedia layanan jasa transportasi online. GOJEK adalah perusahaan berjiwa sosial yang memimpin revolusi industry transportasi Ojek. GO-JEK bermitra dengan para pengendara Ojek berpengalaman di Jakarta meliputi area JABODETABEK, Bandung, Bali Surabaya, Malang dll. GO-JEK menjadi solusi utama dalam pengiriman barang, pesan antar makanan, berbelanja dan berpergian di tengah kemacetan. Aplikasi GO-JEK dapat diunduh pada smartphone yang memiliki sistem operasi iOS dan Android. GO-JEK memanfaatkan media elektronik, dengan itu akses untuk pemesanan jasa ojek lebih mudah bagi konsumen ojek khususnya di kota Bandung. Dengan menggunakan aplikasi di smartphone kemudian gojek akan menjemput konsumennya dan mengantar pelanggan sampai pada tempat tujuannya. GO-JEK juga menyediakan berbagai layanan lain seperti GO-FOOD yang dapat menjemput makanan favorite anda dari mana sajasesuai pesanan anda, kemudian ada GOMART salah satu layanan GO-JEK yang siap sedia untuk membelanjakan kebutuhan anda sehari-hari dan masih banyak lagi fitur-fitur yang diberikan oleh GO-JEK Indonesia.Ttransportasi ini harus tetap memperhatikan kenyamanan, keamanan serta kepuasan konsumennya, bisa menjadi pelanggan yang setia.

Menurut Buttle (2007: 28) kepuasan konsumen membawa dampak yang besar bagi perusahaan. Dengan memertahankan dan memuaskan pelanggan saat ini jauh lebih mudah dibandingkan terus-menerus berupaya menarik atau memprospek pelanggan baru, biaya memertahankan pelanggan lebih murah dibandingkan biaya mencari pelanggan baru. Salah satu faktor yang memengaruhi kepuasan konsumen adalah kinerja dalam hal ini kualitas pelayanan. Parasuraman et al, 1985, yang dikutip (Lupiyoadi, 2001: 148) menyatakan kualitas pelayanan mencakup beberapa aspek yang meliputi: kemampuan memberikan pelayanan dengan segera dan memuaskan (reliability); keinginan para karyawan untuk membantu para pelanggan dan memberikan pelayanan yang tanggap (responsiveness); kemampuan, kesopanan, dan sifat dapat dipercaya para karyawan (assurance); kemudahan dalam melakukan hubungan komunikasi yang baik serta perhatian yang tulus kepada pelanggan (empathy); dan evaluasi fasilitas fisik (tangibles).

Lupiyoadi dan Hamdani (2009: 65), juga mengemukakan bahwa kualitas pelayanan berpengaruh terhadap kepuasan pelanggan, dimana pelayanan yang baik berakibat lebih besar terhadapkepuasan pelanggan. Kualitas pelayanan dapat memengaruhi kepuasan konsumen karena terjadinya interaksi antara konsumen dengan pihak perusahaan. Kepuasan konsumen dapat tercapai apabila kinerja atau hasil yang dirasakan sesuai dengan harapan konsumen. Faktor kedua yang mempengaruhi kepuasan pelanggan adalah fasilitas penunjang yang di dapatkan dalam sarana transaksi, khususnya di era digital seperti sekarang, dimana transaksi dengan fasilitas aplikasi yang 
memadai akan semakin memberi kemudahan bagi konsumen. Dalam aplikasi Gojek terdapat berbagai fitur yang yang cukup lengkap dan lebih memadai dibandingkan aplikasi transportasi online yang lain. Ketika konsumen merasa puas dan nyaman dengan kinerja dan fasilitas yang mereka dapatkan dari suatu produk atau jasa yang diterima maka akan tercipta relasi yang kuat antara konsumen dan pemilik usaha, dimana konsumen akan berkomitmen untuk memakai dan berlangganan jasa kembali di waktu yang akan datang. Menurut Tjiptono (2000:105) tujuan dari suatu bisnis adalah menciptakan kepuasan pelanggan. Kepuasan pelanggan dapat menciptakan hubungan yang harmonis sehingga memberikan dasar yang baik terhadap pembelian ulang dan terciptanya kesetiaan terhadap suatu merek (loyalitas konsumen).

\section{Rumusan Masalah}

1. Bagaimana pengaruh Kinerja Driver terhadap Kepuasan Pelanggan?

2. Bagaimana pengaruh Fasilitas Aplikasi terhadap Kepuasan Pelanggan?

3. Bagaimana pengaruh Kinerja Driver dan Fasilitas Aplikasi terhadap Loyalitas melalui Kepuasan Pelanggan?

\section{Tujuan Peneltian}

1. Untuk menjelaskan pengaruh Kinerja Driver terhadap Kepuasan Pelanggan

2. Untuk menjelaskan pengaruh Fasilitas Aplikasi terhadap Kepuasan Pelanggan

3. Untuk menjelaskan pengaruh Kinerja Driver dan Fasilitas Aplikasi terhadap Loyalitas melalui Kepuasan Pelanggan

\section{KAJIAN PUSTAKA Kinerja}

Performance atau kinerja merupakan hasil atau keluaran dari suatu proses (Nurlaila, 2010:71). Menurut pendekatan perilaku dalam manajemen, kinerja adalah kuantitas atau kualitas sesuatu yang dihasilkan atau jasa yang diberikan oleh seseorang yang melakukan pekerjaan (Luthans, 2005:165). Kinerja adalah hasil yang dicapai dari apa yang diinginkan oleh organisasi. Kinerja atau job performance juga merupakan fungsi dari kapasitas untuk melakukan dengan keahlian, kemampuan, pengetahuan dan pengalaman. Fungsi lainnya yaitu kesempatan melakukan yang berkaitan dengan ketersediaan dan teknologi, kerelaan untuk menggunakan usaha (Kasmir, 2015:183).
Kinerja adalah hasil atau tingkat keberhasilan seseorang secara keseluruhan selama periode tertentu dalam melaksanakan tugas dibandingkan dengan berbagai kemungkinan, seperti standar hasil kerja, target atau sasaran atau kriteria yang telah ditentukan terlebih dahulu telah disepakati bersama (Rivai dan Basri, 2005:50).

Kinerja merupakan hasil kerja dan perilaku kerja yang telah dicapai dalam menyelesaikan tugas - tugas dan tanggung jawab yang diberikan dalam suatu periode tertentu. Kinerja dapat diukur dari kemampuannya menyelesaikan tugas - tugas dan tanggung jawab yang diberikan. Artinya dalam kinerja mengandung unsur standar pencapaian harus dipenuhi, sehingga bagi yang mencapai standar yang telah ditetapkan berarti berkinerja baik begitu pun sebaliknya (Kasmir, 2016:182).

\section{Fasilitas}

Untuk mengemukakan pengertian tentang fasilitas, penulis dapat sajikan beberapa batasan dari para ahli. Menurut Zakiah Daradjat "fasilitas adalah segala sesuatu yang dapat mempermudah upaya dan memperlancar kerja dalam rangka mencapai suatu tujuan. Sedangkan menurut Suryo Subroto " fasilitas adalah segala sesuatu yang dapat memudahkan dan memperlancar pelaksanaan suatu usaha dapat berupa benda-benda maupun uang. Lebih luas lagi tentang pengertian failitas Suhairsimi irikonto berpendapat, "fasilitas dapat diartikan sebagai segala sesuatu yang dapat memudahkan dan memperlancar pelaksanaan segala sesuatu usaha. Adapun yang dapat memudahkan dan melancarkan usaha ini dapat berupa bendabenda maupun uang, dalam penelitian ini fasilitas merupakan aplikasi yang memberi kemudahan dalam transaksi dalam fitur GOJEK. Secara umum fasilitas merupakan alat atau segala sesuatu yang dipergunakan untuk mempermudah dan memperlancar suatu usaha atau pekerjaan.

Fasilitas dapat dibedakan menjadi dua yaitu fasilitas fisik dan fasilitas uang. Fasilitas fisik adalah segala sesuatu yang berupa benda atau yang dapat dibendakan, yang mempunyai peranan dapat memudahkan dan melancarkan suatu usaha. Fasilitas fisik dapat disebut juga dengan fasilitas materiil. Karena fasilitas ini dapat memberi kemudahan dan kelancaran bagi suatu usaha dan biasanya diperlukan sebelum suatu kegiatan berlangsung maka dapat pula 
disebut sebagai saran materiil. Fasilitas uang adalah segala sesuatu yang dapat memberi kemudahan suatu kegiatan sebagai akibat dari "nilai uang'. Fasilitas uang akan dibicarakan dalam bab tersendiri yaitu manajemen keuangan atau manajemen sumber dana.

\section{Kepuasan}

Menurut Park, kepuasan pelanggan merupakan suatu perasaan konsumen sebagai respon terhadap produk barang atau jasa yang telah dikonsumsi (Hasan, 2009:57). Seorang pelanggan, jika merasa puas dengan nilai yang diberikan oleh produk atau jasa, sangat besar kemungkinannya menjadi pelanggan dalam waktu yang lama.Menurut Kotler dan Keller (2007:177 mengatakan bahwa Kepuasan Konsumen adalah perasaan senang atau kecewa seseorang yang muncul setelah membandingkan kinerja (hasil) produk yang dipikirkan terhadap kinerja yang diharapkan.

Memuaskan kebutuhan konsumen adalah keinginan setiap perusahaan. Selain faktor penting bagi kelangsungan hidup perusahaan, memuaskan kebutuhan konsumen dapat meningkatkan keunggulan

dalam persaingan. Konsumen yang puas terhadap produk dan jasa pelayanan cenderung untuk membeli kembali produk dan menggunakan kembali jasa pada saat kebutuhan yang sama muncul kembali dikemudian hari. Hal ini berarti kepuasan merupakan faktor kunci bagi konsumen dalam melakukan pembelian ulang yang merupakanporsi terbesar dari volume penjualan perusahaan.

\section{Faktor Utama dalam Menentukan Tingkat Kepuasan Konsumen}

Dalam menentukan tingkat kepuasan konsumen, terdapat lima faktor utama yang harus diperhatikan oleh perusahaan yaitu :

a. Kualitas produk

Konsumen akan merasa puas bila hasil evaluasi mereka menunjukkan bahwa produk yang mereka gunakan berkualitas.

b. Kualitas pelayanan

Terutama untuk industri jasa. Konsumen akan merasa puas bila mereka mendapatkan pelayanan yang baik atau yang sesuai dengan yang diharapkan.

c. Emosional

Konsumen akan merasa bangga dan mendapatkan keyakinan bahwa orang lain akan kagum terhadap dia bila menggunakan produk dengan merek tertentu yang cenderung mempunyai tingkat kepuasan yang lebih tinggi. Kepuasan yang diperoleh bukan karena kualitas dari produk tetapi nilai sosial yang membuat konsumen menjadi puas terhadap merek tertentu.

d. Harga

Produk yang mempunyai kualitas yang sama tetapi menetapkan harga yang relatif murah akan memberikan nilai yang lebih tinggi kepada konsumennya.

e. Loyalitas

Loyalitas pelanggan merupakan salah satu tujuan inti yang diupayakan dalam pemasaran modern. Loyalitas adalah respon perilaku pembelian yang dapat terungkap secara terus menerus oleh pengambil keputusan dengan memperhatikan satu atau lebih merek alternative dari sejumlah merek sejenis dan merupakan fungsi proses psikologis. (Dharmesta, dalam Dharmayanti, 2006:37-38).

\section{Hipotesis Penelitian}

Berdasarkan teori yang dikatakan sebelumnya, maka dapat dirumuskan hipotesis penelitian sebagai berikut:

H1 : Kinerja driver (X1) berpengaruh positif dan signifikan terhadap kepuasan pelanggan (X3)

H2 :Fasilitas (X2) berpengarih positif dan signifikan terhadap kepuasan pelanggan (X3)

H3 :Kinerja driver (X1) dan fasilitas (X2) secara simultan berpengaruh signifikan terhadap kepuasan pelanggan (X3)

$\mathrm{H} 4$ :Kinerja driver (X1) berpengarih positif dan signifikan terhadap loyalitas (Y)

H5 :Fasilitas (X2) berpengarih positif dan signifikan terhadap loyalitas $(\mathrm{Y})$

H6 : Kepuasan pelanggan (X3) berpengarih positif dan signifikan terhadap loyalitas (Y)

H7 : Kinerja driver (X1), fasilitas (X2), dan kepuasan pelanggan (X3) secara simultan berpengaruh signifikan terhadap loyalitas (Y)

\section{METODE PENELITIAN}

Jenis penelitian ini adalah penelitian kuantitatif. Populasi penelitian adalah pelanggan Gojek di kota Malang. Jumlah sampel yang digunakan ditentukan dengan 
teknik Proportional Random Sampling. Teknik pengambilan sampel dimana semua anggota mempunyai kesempatan yang sama dijadikan sampel, sesuai dengan proporsinya, banyak sedikit populasi. Dalam perhitungan menggunakan Rumus Slovin Umar (2000) dalam Sani dan Maharani (2013 :181) sehingga di dapatkan sampel sebanyak 100 orang.

\section{Skala Pengukuran}

- Dalam penelitian, skor menggunakan skala likert dengan empat kategori:

- Untuk menyatakan sangat setuju diberi skor 4

- Untuk menyatakan setuju diberi skor 3

- Untuk menyatakan kurang setuju diberi skor 2

- Untuk menyatakan tidak setuju diberi skor 1

\section{Metode Analisis Data}

\section{Analisis Jalur (Path Analysis)}

Untuk menguji pengaruh variabel intervening digunakan metode analisis jalur (Path Analysis). Analisis jalur merupakan perluasan dari analisis regresi linear berganda, Tahapan dalam melakukan analisis jalur (path analysis) menurut Solimun (2002) dalam Sani dan Maharani (2013:74) adalah sebagai berikut:

1) Merancang model berdasarkan konsep dan teori pada diagram jalur digunakan dua macam anak panah yaitu:

a. Anak panah satu arah yang menyatakan pengaruh langsung dari variabel bebas ke variabel terikat

b. Anak panah yang menyatakan pengaruh tidak langsung antara variabel bebas terhadap variabel terikat melalui variabel intervening.

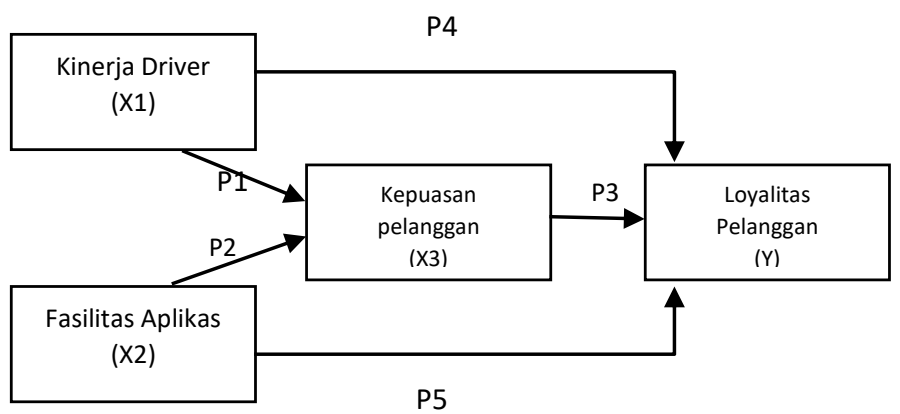

Gambar 1. Model Analisis Jalur (Path Analysis)

Berdasarkan gambar di atas setiap nilai $\mathrm{P}$ menggambarkan jalur dan koefisien jalur antar variabel. Terdapat dua kali pengujian regresi sebagai berikut :

Substruktur 1: $\mathrm{X} 3=\mathrm{a}+\mathrm{B}_{1} \mathrm{X}_{1}+\mathrm{B}_{3} \mathrm{X}_{2}+\varepsilon$

Substruktur 2: $Y=a+B_{1} X_{1}+B_{2} X_{2}+B_{3} X_{3}+\varepsilon$ Keterangan :

$\mathrm{X}_{1}$ : Variabel Kinerja Driver

$\mathrm{X}_{2}$ : Variabel Fasilitas Aplikasi

$\mathrm{X}_{3}$ :Variabel Kepuasan Pelanggan (variabel intervening)

Y: Variabel Loyalitas Pelanggan

B: Koefisien Regresi

a: Koefisien Konstanta

$\varepsilon:$ Error Term

\section{Uji Hipotesis}

i. Uji t

Uji t digunakan untuk menguji apakah suatu variabel bebas berpengaruh terhadap variabel terikat.Dengan ketentuan sebagai berikut :

a. Signifikansi $\leq 0,05$ berarti hipotesis alternatif (Ha) tidak ditolak danHo ditolak

b. Signifikansi $\geq 0,05$ berarti hipotesis alternatif (Ha) ditolak danHo tidak ditolak

ii. Uji F

Uji $F$ digunakan Untuk mengetahui pengaruh antara variabel bebas terhadap variabel terikat secara simultan, maka dilakukan uji hipotesis dengan taraf signifikansi $5 \%(0,05)$.

\section{HASIL PENELITIAN DAN \\ PEMBAHASAN}

Uji Asumsi Klasik

Terdapat tiga jenis asumsi klasik yang dalam penelitian ini.

\section{a. Uji Normalitas}

Uji normalitas digunakan untuk melihat apakah data terdistribusi secara normal atau tidak. Dalam penelitian ini, uji normalitas dilakukan dengan cara melihat nilai probabiltas Jarque-Bera.

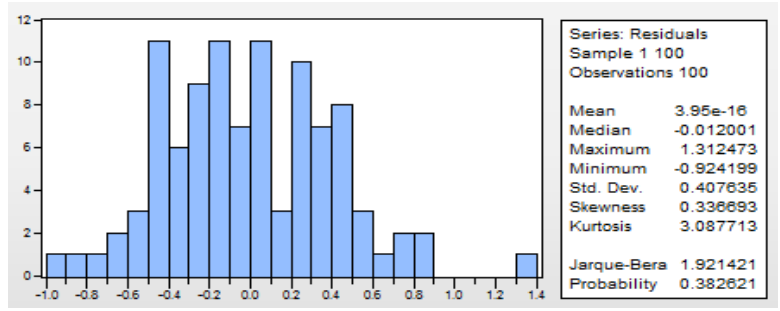

\section{Gambar 2 Hasil Uji Normalitas}

Sumber: Hasil penelitian yang diolah (2019) 
Berdasarkan gambar di atas dapat diketahui bahwa nilai probabilitas Jarque-Bera $(0,38)$ lebih besar dari 0,05 sehingga dapat dikatakan bahwa data yang digunakan dalam model sudah terdistribusi secara normal.

\section{b. Uji Multikolineritas}

Uji Multikolineritas digunakan untuk melihat ada atau tidaknya hubungan antar variabel bebas didalam model. Berikut adalah hasil uji multikolineritas yang dilakukan dalam penelitian ini:

Tabel 1 hasil uji multikolineritas

\begin{tabular}{cccc}
\hline \hline & $\begin{array}{c}\text { Coefficient } \\
\text { Variance }\end{array}$ & $\begin{array}{c}\text { Uncentered } \\
\text { VIF }\end{array}$ & $\begin{array}{c}\text { Centered } \\
\text { VIF }\end{array}$ \\
\hline \hline Cariable & 0.410236 & 239.4018 & NA \\
X1 & 0.026521 & 155.9661 & 1.158667 \\
X2 & 0.027878 & 157.6194 & 1.155256 \\
X3 & 0.024847 & 134.2641 & 1.284203 \\
\hline \hline
\end{tabular}

Sumber: Hasil penelitian yang diolah (2019)

Berdasarkan tabel di atas, dapat diketahui bahwa nilai VIF dari X1, X2, dan X3 lebih kecil dari 10. Hal ini menunjukkan bahwa tidak terjadi adanya multikolineritas di dalam model. Sehingga dapat dikatakan bahwa variabel bebas yang digunakan dalam penelitian ini lolos uji multikolinieritas.

\section{c. Uji Heteroskedastisitas}

Uji heteroskedastisitas digunakan untuk menguji apakah varian dari kesalahan pengganggu tidak konstan untuk semua variabel bebas dalam peneltian. Hasil uji heteroskedastisitas dalam penelitian ini, dapat dilihat pada tabel dibawah:

\section{Tabel 2 hasil uji heteroskedastisitas}

Heteroskedasticity Test: Breusch-Pagan-Godfrey

\begin{tabular}{lclc}
\hline \hline $\begin{array}{l}\text { F-statistic } \\
\text { Obs*R- } \\
\text { squared }\end{array}$ & 1.025606 & Prob. F(3,96) & 0.3849 \\
$\begin{array}{l}\text { Scaled } \\
\text { explained } \\
\text { SS }\end{array}$ & 3.105488 & Prob. Chi-Square(3) & 0.3756 \\
\hline \hline
\end{tabular}

Berdasarkan tabel di atas dapat diketahui bahwa nilai probabilitas Chi Square $(0,376)$ lebih besar dari 0,05 . Sehingga, dapat dikatakan tidak terjadi heteroskedastisitas di dalam model. Dengan kata lain, model penelitian bersifat homoskedastisitas dan lolos uji heteroskedastisitas.

\section{Uji Hipotesis}

Uji hipotesis digunakan untuk menetapkan dasar penelitian guna mengumpulkan bukti untuk menentukan keputusan apakah menolak atau menerima kebenaran dari asumsi yang dibuat oleh peneliti.

Tabel 3 Hasil Uji Hipotesis

\begin{tabular}{|c|c|c|c|c|}
\hline \multirow[b]{2}{*}{$\begin{array}{l}\mathbf{N} \\
\text { o. }\end{array}$} & \multirow[b]{2}{*}{ Uji Hipotesis } & \multicolumn{2}{|c|}{ Hasil } & $\begin{array}{c}\text { Keteran } \\
\text { gan }\end{array}$ \\
\hline & & $\begin{array}{c}\mathrm{t} \\
\text { hitun } \\
\mathrm{g} / \mathrm{F} \\
\text { hitun } \\
\mathrm{g}\end{array}$ & $\begin{array}{l}\text { t kritis } \\
/ \mathrm{F} \\
\text { kritis }\end{array}$ & Hipotesa \\
\hline 1 & $\begin{array}{l}\text { Pengaruh kinerja driver } \\
\text { (X1) terhadap kepuasan } \\
\text { pelanggan (X3) }\end{array}$ & 3,348 & 1,660 & $\begin{array}{r}\mathrm{H} 1 \\
\text { diterima }\end{array}$ \\
\hline 2 & $\begin{array}{lr}\text { Pengaruh fasilitas (X2) } \\
\text { terhadap } \\
\text { pelanggan }(\mathrm{X} 3)\end{array}$ & 3,311 & 1,660 & $\begin{array}{r}\mathrm{H} 2 \\
\text { diterima }\end{array}$ \\
\hline 3 & $\begin{array}{l}\text { Pengaruh kinerja driver } \\
\text { (X1) dan fasilitas (X2) } \\
\text { terhadap } \\
\text { pelanggan (X3) }\end{array}$ & $\begin{array}{c}13,69 \\
3\end{array}$ & 3,090 & $\begin{array}{r}\mathrm{H} 3 \\
\text { diterima }\end{array}$ \\
\hline 4 & $\begin{array}{l}\text { Pengaruh kinerja driver } \\
\text { (X1) terhadap loyalitas (Y) }\end{array}$ & 1,793 & 1,660 & $\begin{array}{r}\mathrm{H} 4 \\
\text { diterima }\end{array}$ \\
\hline 5 & $\begin{array}{l}\text { Pengaruh fasilitas (X2) } \\
\text { terhadap loyalitas (Y) }\end{array}$ & 0,655 & 1,660 & $\begin{array}{r}\mathrm{H} 5 \\
\text { ditolak }\end{array}$ \\
\hline 6 & $\begin{array}{lr}\text { Pengaruh } & \text { kepuasan } \\
\text { pelanggan (X3) } & \text { terhadap } \\
\text { loyalitas (Y) } & \\
\end{array}$ & 2,751 & 1,660 & $\begin{array}{r}\mathrm{H6} \\
\text { diterima }\end{array}$ \\
\hline 7 & $\begin{array}{l}\text { Pengaruh kinerja driver } \\
(\mathrm{X} 1) \text {, fasilitas (X2), dan } \\
\text { kepuasan pelanggan (X3) } \\
\text { terhadap loyalitas (Y) }\end{array}$ & 6,796 & 2,700 & $\begin{array}{r}\mathrm{H} 7 \\
\text { diterima }\end{array}$ \\
\hline & er: Hasil Penelitian & 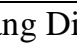 & 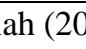 & \\
\hline
\end{tabular}

Berdasarkan hasil penelitian dapat dikatakan bahwa pengaruh kinerja driver( $\mathrm{x} 1)$ terhadap kepuasan pelanggan (x3) Gojek menunjukkan adanya pengaruh yang signifikan. Hal ini ditunjukkan dengan nilai t hitung $(3,348)$ yang lebih besar daripada $t$ kritis $(1,660)$. Dengan demikian, penelitian ini menerima hipotesis alternatif yang telah dibentuk sebelumnya.

Pengaruh fasilitas (x2) terhadap kepuasan pelanggan (x3) Gojek berdasarkan hasil penelitian menunjukkan adanya pengaruh yang signifikan. Hal ini ditunjukkan dengan nilai thitung $(3,311)$ yang lebih besar daripada t kritis(1,660). Dengan demikian, dapat dikatakan bahwa penelitian ini menerima hipotesis alternatif yang telah dibentuk sebelumnya.

Sedangkan Berdasarkan hasil penelitian ini, pengaruh kinerja driver $(\mathrm{x} 1)$ dan fasilitas (x3) secara simultan terhadap kepuasan pelanggan (x3) Gojek menunjukkan adanya pengaruh yang signifikan. Hal ini ditunjukkan dengan nilai F hitung $(13,693)$ yang lebih besar 
daripada F kritis (3,090). Dengan demikian, penelitian ini menerima hipotesis alternatif yang telah dibentuk sebelumnya.

Pengaruh kinerja driver (x1)terhadap loyalitas pelanggan (y) Gojek berdasarkan hasil penelitian menunjukkan adanya pengaruh yang signifikan. Hal ini ditunjukkan dengan nilai $\mathrm{t}$ hitung $(1,793)$ yang lebih besar daripada t kritis $(1,660)$. Dengan demikian, penelitian ini menerima hipotesis alternatif yang telah dibentuk sebelumnya.

Pengaruh fasilitas (x2) terhadap loyalitas pelanggan (y) Gojek berdasarkan hasil penelitian menunjukkan adanya pengaruh yang tidak signifikan. Hal ini ditunjukkan dengan nilai thitung $(0,655)$ yang lebih kecil daripada $t$ kritis $(1,660)$. Dengan demikian, penelitian ini menerima hipotesis null yang telah dibentuk sebelumnya.

Pengaruh kepuasan (x3) terhadap loyalitas pelanggan (y) Gojek berdasarkan hasil penelitian menunjukkan adanya pengaruh yang signifikan. Hal ini ditunjukkan dengan nilai $\mathrm{t}$ hitung $(2,751)$ yang lebih besar daripada t kritis $(1,660)$. Dengan demikian, penelitian ini menerima hipotesis alternatif yang telah dibentuk sebelumnya.

Pengaruh kinerja drive $r(\mathrm{x} 1)$, fasilitas (x2), dan kepuasan (x3) secara simultan terhadap loyalitas (y) pelanggan Gojek berdasarkan hasil penelitian menunjukkan adanya pengaruh yang signifikan. Hal ini ditunjukkan dengan nilai $\mathrm{F}$ hitung $(6,796)$ yang lebih besar daripada F kritis (2,700). Dengan demikian dapat dikatakan bahwa penelitian ini menerima hipotesis alternatif.

\section{Hasil Path Analysis}

Setelah uji hipotesis, perlu dilakukan Path Analysis untuk dapat melihat arah pengaruh variabel kinerja driver dan fasilitas terhadap loyalitas. Path Analysis dalam penelitian ini dilakukan dengan meregresi dua model substruktur. Hasil Path Analysis dalam penelitian ini dapat dilihat pada gambar di bawah ini:

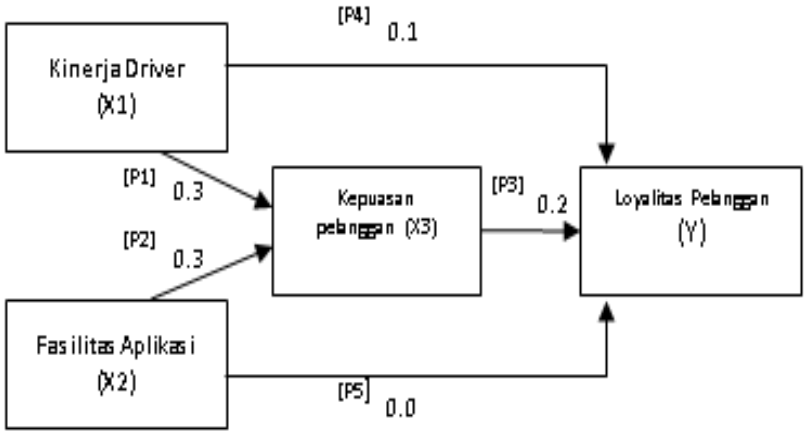

\section{Gambar 3 Hasil Path Analysis}

Faktor utama yang membedakan perusahaan jasa satu dengan lainnya yaitu terletak pada kualitas layanan pelanggan (Djati dan Darmawan:2005). Perusahaan-perusahaan jasa terus berupaya untuk terus meningkatkan kualitas pelayanannya dalam menghadapi persaingan yang sangat kompetitif. Gojek yang juga termasuk dalam perusahaan di bidang jasa membutuhkan kualitas pelayanan yang baik sebagai senjata ampuh dalam hal keunggulan perusahaan.Kualitas pelayanan yang baik dapat tercipta melalui kinerjadrivernya. Hal ini dikarenakan driver Gojek merupakan karyawan front stage yang berkomunikasi langsung dengan pelanggan dimana karyawan front stage beperan sebagai human attribute yang berkewajiban untuk memuaskan kebutuhan dan keinginan pelanggan.

Hasil penelitian ini menunjukkan kinerja driver berpengaruh positif dan signifikan terhadap kepuasan pelanggan. Perubahan yang terjadi pada variabel kinerja driverakan berpengaruh terhadap kepuasan pelanggan. Pengaruh positif atau searah menunjukkan arti bahwa ketika terjadi peningkatan kinerja driver, maka kepuasan pelanggan juga akan meningkat. Begitu pula sebaliknya, jika kinerja driver menurun, maka kepuasan pelanggan juga akan mengalami penurunan. Hasil ini sesuai dengan penelitian Hermawanti (2017) yang juga menemukan bahwa kualitas pelayanan yang berasal dari kinerja pegawai mempengaruhi peningkatan kepuasan.

Menurut Kotler dalam Aryani dan Rosinta (2010), kepuasan pelanggan adalah tingkat perasaan seseorang setelah membandingkan kinerja (hasil) yang ia rasakan dengan harapan yang ia miliki terhadap produk atau jasa yang mereka konsumsi. Jika kinerja dibawah harapan, maka pelanggan tidak puas. 
Namun, jika kinerja memenuhi harapan pelanggan, maka pelanggan akanmerasa puas. Dengan kata lain, semakin baik kinerja yang diberikan oleh seorang driver Gojek, maka semakin besar pula peluangnya dalam memuaskan pelanggan.

Hasil lain dari penelitian ini menunjukkan bahwa fasilitas berpengaruh positif dan signifikan terhadap kepuasan pelanggan. Perubahan yang terjadi pada variabel fasilitasakan menyebabkan kepuasan pelanggan berubah. Pengaruh positif atau searah menunjukkan arti bahwa terjadinya peningkatan fasilitas akanmeningkatkan kepuasan pelanggan. Begitu pula sebaliknya, jika fasilitas yang diberikan menurun, maka kepuasan pelanggan juga akan mengalami penurunan. Hasil ini sesuai dengan penelitian Krisdayanto, dkk (2018) yang juga menemukan bahwa fasilitas berpengaruh positif dan signifikan terhadap kepuasan pelanggan.

Fasilitasyang mumpuni memberikan nilai kepuasan tersendiri kepada pelanggan. Berbagai jenis fitur yang ditawarkan oleh Gojek seperti Go-Ride, Go-Car, Go-Food, Go-Clean, dll memberi kemudahan bagi pelanggan dalam memenuhi kebutuhan sehari-harinya. Hal ini tentunya memberikan gambaran tentang adanya kepuasan yang dirasakan oleh pelanggan atas fasilitas-fasilitas yang ditawarkan oleh Gojek.Selain itu, saat ini Gojek masih terus berusaha mengembangkan aplikasinya untuk tetap menjaga kepuasaan pelanggan melalui sejumlah inovasi terkini.

Kinerja driver berpengaruh positif dan signifikan terhadap loyalitas. Perubahan yang terjadi pada variabel kinerja driver akan menyebabkan loyalitas berubah. Pengaruh positif atau searah menunjukkan arti bahwa ketika terjadi peningkatan kinerja driver, maka loyalitas juga akan meningkat. Begitu pula sebaliknya, jika kinerja driver menurun, maka tingkat loyalitas pelanggan juga akan mengalami penurunan. Hasil ini sesuai dengan penelitian Djati dan Darmawan (2005) yang menyatakan bahwa kesetiaan (loyalitas) secara signifikan dibentuk dari kinerja karyawan, kepuasan pelanggan, dan kepercayaan.

Kinerja driver merupakan salah satu indikator dalam menentukan tingkat loyalitas pelanggan dalam menggunakan jasa yang ditawarkan oleh pihak Gojek. Sofyan, dkk (2013) mengatakan bahwa kinerja yang baik memberikan dorongan bagi pelanggan untuk terus menjalin ikatan hubungan yang baik pula.
Dalam jangka panjang hubungan ini dapat mendorong perusahaan untuk terus memaksimalkan pelayanan yang ditawarkan dalam memenuhi kebutuhan pelanggan melalui pemaksimalan pengalaman yang menyenangkan dalam penggunaan aplikasi Gojek. Hal ini tentunya akan membentuk loyalitas perusahaan terhadap konsumen begitupula sebaliknya.

Variable Fasilitas tidak berpengaruh signifikan terhadap loyalitas. Hasil yang sama juga ditemukan oleh Pitria dan Mulyanto (2016) dimana fasilitas tidak berpengaruh terhadap komitmen sehingga tidak berdampak pada loyalitas pelanggan. Hal ini menunjukkan bahwa fasilitas yang diberikan oleh Gojek tidak sepenuhnya mempengaruhi tingkat loyalitas konsumen terhadap pemakaian aplikasi tersebut. Adanya pesaing yang sama dalam transportasi online membentuk rasionalitas konsumen untuk memilih provider yang memberikan promo sebagaimana kebutuhan konsumen.

Variabel kepuasan pelanggan berpengaruh positif dan signifikan terhadap loyalitas. Perubahan yang terjadi pada variabel kepuasan pelangganakan menyebabkan tingkat loyalitas pelanggan berubah. Pengaruh positif atau searah menunjukkan arti bahwa ketika terjadi peningkatan kepuasan pelanggan, maka loyalitas juga akan mengalami peningkatan. Begitu pula sebaliknya, jika kepuasan pelanggan menurun, maka loyalitas juga akan mengalami penurunan. Hasil penelitian ini sesuai dengan penelitian yang dilakukan oleh Aryani dan Rosinta (2010) dimana kepuasan pelanggan mempunyai pengaruh positif terhadap loyalitas pelanggan.

Kepuasan merupakan indikasi terbentuknya sikap loyal atau setia pelanggan terhadap suatu perusahaan. Semakin besar tingkat kepuasan yang dirasakan oleh pelanggan, akan meningkatkan dorongan pelanggan untuk terus menggunakan produk atau jasa yang ditawarkan oleh suatu perusahaan. Sikap inilah yang akan membentuk loyalitas pelanggan yang nantinya akan menciptakan keuntungan bagi perusahaan baik dalam jangka pendek maupun jangka panjang.

Analisis Path dalam penelitian ini bertujuan untuk mengukur pengaruh langsung maupun tidak langsung kinerja driver dan fasilitas terhadap loyalitas melalui variabel intervening kepuasan pelanggan. Pengaruh langsung kinerja driver terhadap loyalitas 
sebesar 0,179 sedangkan pengaruh tidak langsung kinerja driver ke loyalitas bernilai $(0,306 \times 0,289)$ atau sebesar 0,088 . Dengan kata lain, total pengaruh kinerja driver terhadap loyalitas sebesar 0,267 dimana pengaruh langsung kinerja driver terhadap loyalitas lebih besar dibandingkan pengaruh tidak langsungnya. Disisi lain, pengaruh langsung fasilitas terhadap loyalitas ditemukan tidak signifikan, sedangkan pengaruh tidak langsung fasilitas ke loyalitas bernilai $(0,302 \times 0,289)$ atau sebesar 0,087 dimana nilai tersebut juga menunjukkan pengaruh total fasilitas terhadap loyalitas.

\section{KESIMPULAN DAN SARAN \\ Kesimpulan}

Dari Penelitian ini dapat disimplkan:

Adanya pengaruh positip dan signifikan antara kinerja driver (x1) terhadap kepuasan pelanggan (x3) Gojek. Hal ini ditunjukkan dengan nilai t hitung $(3,348)$ yang lebih besar daripada t kritis $(1,660)$.

Adanya pengaruh positip dan signifikan antara fasilitas (x2) terhadap kepuasan pelanggan (x3) Gojek. Hal ini ditunjukkan dengan nilai t hitung $(3,311)$ yang lebih besar daripada $t$ kritis(1,660).

Adanya pengaruh positip dan signifikan antara kinerja driver (x1)dan fasilitas (x3) secara simultan terhadap kepuasan pelanggan (x3) Gojek. Hal ini ditunjukkan dengan nilai $F$ hitung $(13,693)$ yang lebih besar daripada F kritis $(3,090)$.

Adanya pengaruh positip dan signifikan antara kinerja driver (x1)terhadap loyalitas pelanggan (y) Gojek. Hal ini ditunjukkan dengan nilai t hitung $(1,793)$ yang lebih besar daripada $t$ kritis $(1,660)$.

Adanya pengaruh tidak signifikan antara fasilitas (x2) terhadap loyalitas pelanggan (y) Gojek. Hal ini ditunjukkan dengan nilai t hitung $(0,655)$ yang lebih kecil daripada t kritis $(1,660)$.

Adanya pengaruh positip dan signifikan antara kepuasan (x3) terhadap loyalitas pelanggan (y) Gojek. Hal ini ditunjukkan dengan nilai t hitung $(2,751)$ yang lebih besar daripada $t$ kritis $(1,660)$.

Adanya pengaruh positip dan signifikan antara kinerja drive $r(\mathrm{x} 1)$, fasilitas (x2), dan kepuasan (x3) secara simultan terhadap loyalitas (y) pelanggan Gojek. Hal ini ditunjukkan dengan nilai $\mathrm{F}$ hitung $(6,796)$ yang lebih besar daripada $\mathrm{F}$ kritis $(2,700)$.

\section{Saran}

adalah:

Adapun saran yang dapat diberikan

Gojek hendaknya terus meningkatkan pelayanan pada konsumen melalui kinerja driver yang lebih baik agar kepuasan konsumen terus meningkat.

Gojek hendaknya terus meningkatkan fasilitas yang sesuai dengan harapan dan kebutuhan pelanggan agar kepuasan pelanggan terus bertambah.

Gojek hendaknya terus meningkatkan kualitas pelayanan agar konsumen merasa puas hingga pada akhirnya, pada jangka panjang loyalitas konsumen terbentuk. Gojek hendaknya memfokuskan peningkatan fasilitas agar dapat menjadi faktor keunggulan ketika harus bersaing dengan provider di industri yang sama.

\section{DAFTAR PUSTAKA}

Arikunto, Suharsimi. 2002. Prosedur Penelitian. Rineka Cipta Jakarta.

Aryani, Dwi dan Rosinta, Febrina. 2010. Pengaruh Kualitas Layanan terhadap Kepuasan Pelanggan dalam Membentuk Loyalitas Pelanggan. Jurnal Ilmu Administrasi dan Organisasi.

Gaol, Jimmy L. 2014. Human Capital. Penerbit PT. Gramedia Widiasarana Indonesia. Jakarta.

Hermawanti, Putri Yuliana. 2017. Pengaruh Kinerja dan Kelengkapan Fasilitas Pelayanan Medis Terhadap Kepuasan Pasien Pengguna BPJS Kesehatan di Puskesmas Windusari Kabupaten Magelang. Jurnal Universitas Negeri Yogyakarta.

Krisdayanto, I., Haryono, A. T., dan Gagah, E. 2018. Analisis Pengaruh Harga, Kualitas Pelayanan, Fasilitas, dan Lokasi Terhadap Kepuasan Konsumen di I Cafe Lina Putra Net Bandungan. Journal of Management, 4(4).

Pitria dan Mulyanto, Heru. Kualitas Layanan dalam Mempengaruhi Komitmen dan Loyalitas Pelanggan Restoran Cepat Saji. Jurnal Manajemen Kewirausahaan.

Schermerhorn, Jhon R. 2000. Manajemen. Buku II. Terjemahan. Edisi ketiga. Penerbit Andi. Yogyakarta. 
Sofyan, I. L., Pradhanawati, A., dan Nugraha, H. S. 2013. Pengaruh fasilitas dan kualitas pelayanan terhadap loyalitas, melalui kepuasan konsumen sebagai variabel intervening pada star clean car wash Semarang. Jurnal Ilmu Administrasi Bisnis. 